\title{
Proteins, patients and plasma
}

It gives me great pleasure to be writing this editorial for the first issue of the Australian Supplement to The Journal of Laryngology \& Otology to contain 100 per cent local content. I would like to thank the contributors, their senior authors, the reviewers and the JLO editorial board for making this happen.

In this supplement, we have articles covering a huge spectrum of otolaryngology (hence the rather bizarre title of this editorial).

Micro-ribonucleic acids (micro-RNAs) are the new buzz-word in molecular biology circles. Whilst we previously thought that by studying messenger RNA (mRNA) and its encoded proteins we would find answers to all our research questions, it now turns out that micro-RNAs can turn off the whole process, completely altering the mRNA message we thought we were so clever in identifying. There has been a huge amount of work done on the role of micro-RNAs in oncogenesis, but still relatively little on their involvement in head and neck cancer. The review article from Gunawardena et al. ${ }^{1}$ looks at what is known about micro-RNAs in laryngeal cancer, and how future research in this area might lead to new treatment modalities.

Butler and colleagues' article ${ }^{2}$ assessing the safety and efficacy of implantable hearing aids provides us with excellent evidence with which to continue to progress clinically in this exciting field.

Elliott $e t$ al. ${ }^{3}$ provide reassuring data that the finding of an incidental papillary microcarcinoma is not always bad news for the patient.

Naidoo et $a l .{ }^{4}$ present a new quality of life instrument for patients with chronic rhinosinusitis. Given the fact that Australia has such a high prevalence of this disease, having an instrument that is tailored to the disease spectrum we all see day to day will no doubt prove to be extremely beneficial.

Chin and colleagues' paper ${ }^{5}$ looking at the beneficial effects of plasma technology in skull base surgery provides further evidence of the advantages of this unique tissue ablation method.

The Melbourne academic ear group provides us with an attractive new method of bone-anchored hearing aid insertion, ${ }^{6}$ and an excellent quality of life paper $^{7}$ on cutaneous squamous cell cancer of the head and neck concludes the section on original research.

Whilst we are trying to reduce the number of case reports in favour of good quality review articles, I hope the four final articles ${ }^{8-11}$ published in this edition will provide you with useful information on rare diagnoses.

A SIMON CARNEY

ASOHNS Supplement Editor simoncarney@me.com

References

1 Gunawardena I, Fitzgerald J, Morley A, Hussey DJ, Woods CM, Carney AS. Micro-ribonucleic acids in head and neck cancer: an introduction. J Laryngol Otol 2013;127(suppl 2):S2-S7

2 Butler CL, Thavaneswaran P, Lee IH. Efficacy of the active middle-ear implant in patients with sensorineural hearing loss. J Laryngol Otol 2013;127(suppl 2):S8-S16

3 Elliott MS, Gao K, Gupta R, Chua EL, Gargya A, Clark J. Management of incidental and non-incidental papillary thyroid microcarcinoma. J Laryngol Otol 2013;127(supp1 2):S17-S23

4 Naidoo Y, Tan N, Singhal D, Wormald PJ. Chronic rhinosinusitis assessment using the Adelaide Disease Severity Score. J Laryngol Otol 2013;127(suppl 2):S24-S28

5 Chin D, Snidvongs K, Sacks R, Harvey RJ. Collateral thermal injury during endoscopic skull base surgery from endonasal $\mathrm{CO}_{2}$ laser and coblation. J Laryngol Otol 2013;127(suppl 2): $\mathrm{S} 29-\mathrm{S} 32$

6 Husseman J, Szudek J, Monksfield P, Power D, O'leary S, Briggs R. Simplified bone-anchored hearing aid insertion using a linear incision without soft tissue reduction. J Laryngol Otol 2013;127(suppl 2):S33-S38

7 Wang AY, Palme CE, Wang JT, Morgan GJ, Gebski V, Gilchrist J, Veness MJ. Quality of life assessment in patients treated for metastatic cutaneous squamous cell carcinoma of the head and neck. J Laryngol Otol 2013;127(suppl 2):S39-S47

8 Tan CY, Chong S, Shaw C-K L. Primary mastoid cyst. J Laryngol Otol 2013;127(suppl 2):S48-S50

9 Wickham N, Crawford A, Carney AS, Goss AN. Bisphosphonate-associated osteonecrosis of the external auditory canal. J Laryngol Otol 2013;127(suppl 2):S51-S53

10 Mittal N, Collignon P, Pham T, Robbie M. Cryptococcal infection of the larynx: case report. J Laryngol Otol 2013;127(suppl 2):S54-S56

11 Santa Maria PL. Sigmoid sinus dehiscence resurfacing as treatment for pulsatile tinnitus. J Laryngol Otol 2013;127(suppl 2): S57-S59 